\title{
PERCEPTION OF THE SEVERITY OF COVID-19 CONTAGION IN THE RISK GROUP. A COMPARATIVE STUDY AT THE FIRST AND THE NINTH MONTHS OF COMPULSORY ISOLATION.
}

\author{
(iD) CEBERIO, Marcelo R.* \\ (D) BENEDICTO, Gabriela \\ (iD) JONES, Gilda \\ (iD) CALLIGARO, Carolina
}

\author{
(iD) AGOSTINELLI, Jesica \\ (D) COCOLA, Facundo \\ (iD) DÍAZ VIDELA, Marcos \\ (iD) DAVERIO, Romina
}

Research laboratory in neurosciences and social sciences. Argentine Systemic School. Flores University, UFLO, Argentina. *Corresponding author (marcelorceberio@gmail.com)

\section{COPYRIGHT NOTICE:}

\section{CITE THIS PAPER:}

Ceberio, Marcelo R.; Agostinelli, Jesica; Benedicto, Gabriela; Cocola, Facundo; Jones, Gilda; Díaz Videla, Marcos; Calligaro, Carolina; Daverio, Romina (2022). "Perception of the severity of COVID-19 contagion in the risk group. A comparative study at the first and the ninth months of compulsory isolation" Journal of Social Sciences: Transformations \& Transitions (JOSSTT) 2 (03):12. DOI: https://doi.org/10.52459/josstt23120122

\section{ABSTRACT}

After the continued extension of the quarantine due to the COVID-19 pandemic, it was proposed to investigate the perception of the severity of contagion in the risk group of the population. For this purpose, a descriptive cross-sectional study was carried out through the online distribution of surveys, consisting of a sociodemographic questionnaire and questions related to the perception of the severity of the disease. Two comparative moments were considered: the first month and the ninth month of quarantine. The random sample consisted of 4268 individuals, of whom 1006 respondents stated that they were part of a risk group. Regarding the results, it was observed that although the perception of the risk of contagion decreased over the months, the highest risk remained "very high" (in the first month - 46.7 percent and in the ninth month - 38.5 percent), increasing the values of "medium risk" (in the first month - 20.4 percent; in the ninth month - 28.6 percent) and "high risk" (in the first month - 16.0 percent; in the ninth month - 20.8 percent). However, the difference was not statistically significant (the Wilcoxon rank test was applied and a value of $p=0.6$ was obtained). In turn, the research allows us to compare the results with those of the perception of the population as a whole and compare the values of the risk group who contracted the virus, with whom they did not.

\section{KEYWORDS}

COVID-19, Perception, Quarantine, Severity, Risk Group. 


\section{INTRODUCTION}

\section{Pandemic, Isolation, and Uncertainty}

On March 11, 2020, the World Health Organization (WHO) declared the global spread of the Covid19 virus a pandemic. In Argentina, mandatory quarantine was declared on March 20, 2020 (Decree 297/2020). From the beginning, it was sought to determine the population at greatest risk of becoming seriously ill from the virus, in order to place greater emphasis on hygiene and sanitary security measures.

The risk group was (and is) the most careful of the contagion of COVID-19 and, in turn, was the population most impacted by isolation, social distance, and the impossibility of returning to the work and recreational environment. The emphasis placed on physical health implied emotional and mental wear and tear that led to the appearance of anxiety, fear of death in the context of COVID-19, depression, stress, insomnia, denial, anger, among others (Galindo-Vázquez et al., 2020; Lozano-Vargas, 2020; Tomás-Sábado, 2020).

The general population developed various clinical and psychological symptoms, including high levels of stress, anxiety, depression, and anguish, arising in the context of pandemic and confinement (Brown et al., 2020; Wang et al., 2020). Studies carried out on the emotional and psychological repercussions of COVID-19 have differentiated the general population from the population at risk. The groups considered at risk of contracting COVID-19 are determined according to the official website of the Argentine government (www.argentina.gob.ar), which is mostly consistent with the descriptions that appear on most pages and internet sites in Argentina and the world, namely:

1. Asthma, moderate to severe.

2. Chronic kidney disease, under treatment with dialysis.

3. Chronic liver diseases, including cirrhosis.

4. Chronic lung diseases, such as chronic obstructive pulmonary emphysema (COPD), including cystic fibrosis, chronic bronchitis, and idiopathic pulmonary fibrosis.

5. Diabetes (both type 1, type 2, or gestational diabetes).

6. Immuno-depression due to different pathologies or conditions, for example, cancer treatment, immune system deficits, transplants, HIV patients with a low CD4 cell count or no HIV treatment, long-term use of corticosteroids, and other medications that weaken the immune system.

7. Older adults, 65 years of age or older.

8. Hemoglobin disorders such as sickle cell anemia and thalassemia.

9. Older adults living in nursing homes or long-term care facilities.

10. Heart disease, including congenital heart disease, cardiomyopathy, heart failure, coronary artery disease, and pulmonary hypertension.

11. Severe obesity, which is defined as a Body Mass Index (BMI) of 40 or more. 
Beyond the organic factors of the risk groups to be infected, Zandifar and Badrfam (2020) point out that factors such as uncertainty, geometric reproduction of the virus, the severity of COVID-19, the risk of contagion, the unpredictability of completion The pandemic and quarantine, among others, have an impact on mental health. This contextual panorama is aggravated by false news about contagion, preventive measures and action on the virus, and the understanding and compliance with regulations imposed by health authorities (Bao, et al, 2020).

Most research concludes that, in the first quarantine period, fear, anguish, and anxiety stood out as an emotional triad (Aliaga Tinoko, 2020; Inchausti et al., 2020; Schmidt et al., 2020; Ceberio, 2020). It was enhanced by the great uncertainty that accompanies the pandemic, affecting different areas of daily life (Johnson, et al., 2020; Ceberio, 2020; Medina, 2020; Rodríguez-Castellanos and San-Martín-Albizuri, 2020).

In 2020 and 2021, numerous investigations have been carried out on COVID-19, some of them on the psychological repercussions of isolation. They point out that there are indicators of anxiety, anger, aggression, panic disorders, sleep disorders, hopelessness, annoyance, distress that manifest themselves in people due to confinement during pandemics (Khan et al, 2020). In Spain, levels of stress, anxiety, and depression were investigated in the first phase of the Covid-19 outbreak and the indicators of psychological symptoms according to age, chronicity and confinement have been studied (Ozamiz-Etxebarria et al, 2020). The results showed that, although symptom levels have been generally low at the beginning of the alarm, the younger population (18-25 years) and with chronic diseases have referred higher symptoms than the rest of the population. They presented higher averages in stress, anxiety, and depression compared to the groups of 2660 years and older than 60 . A higher level of symptoms has also been detected from confinement. In China, a population sample of 1210 participants during the initial phase of the Covid-19 outbreak, whose results refer to the presence of the following symptoms (moderate to severe): depression (16.5\%), anxiety (28.8\%), stress $(8.1 \%)$ and a significant association $(\mathrm{p}<0.05)$ between self-assessed health status with higher levels of stress, anxiety, and depression, especially in female students (González-Jaimes et. al, 2020). Anxiety (35.1\%), depression (20.1\%), and sleep disorder (18.2\%) during the first phase of confinement by Covid-19 in a Chinese population (Huang \& Zhao, 2020). Del Mar Morero et al (2020) carry out a systematic review on psychological factors in quarantine situations, high levels of stress, anxiety, depression, and anguish were found, and the analysis of the results indicated that a positive emotional style was associated with a lower risk of developing diseases.

In India, for example, suicides associated with fear of being infected by Covid-19 were recorded (Goyal et al., 2020). Isolation has also caused numerous behavioral and emotional reactions that were reflected in various investigations such as studies on information (Masip, et al. 2020), drug use in isolation (Wei, \&

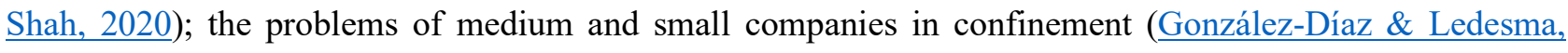
2020); or the measurement of variables of anxiety, stress, and depression (Ozamiz-Etxebarria, et al., 2020), 
depression, stress and suicidal ideation (Arias Molina, et al., 2020; Huarcaya-Victoria, 2020); anxiety symptoms such as insomnia, loss of appetite, worry, fatigue (Moreno-Proaño, 2020).

Other authors highlight the presence of anxiety and fear of death in the context of COVID-19 (Tomás-

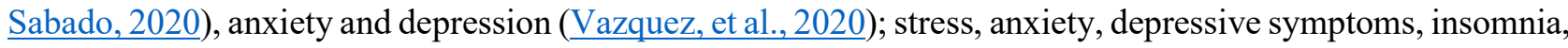
denial, anger (Lozano-Vargas, 2020); or scientific articles that refer to anxiogenic manifestations in different situations and populations in the context of the pandemic (Guzmán, 2020; Saravia-Bartra, et al. 2020; Santamaría, et al 2020; Molero Jurado, et al, 2020; Jerves Mora, 2020; Sanchez \& Aguila, 2020). Also, the study of symptoms and organic pathologies such as immunodeficiencies, heart disease, diabetes, hypertension, respiratory pathologies, among others (Cao, 2020; Clerkin et al., 2020; Fang, et al., 2020; Serra Valdez, 2020).

The media played a fundamental role during the pandemic since they were the contact that the population had to find out about what was happening in the country and the world in general. Television, radio, and the internet were in charge of transmitting, hour after hour, the news regarding the advance of COVID19. For this reason, the media had a great influence on the perception that people had of the pandemic in general and the severity of the spread of the virus in particular (Mejia et al. 2020; WHO, 2020a; PAHO, 2020). However, the information transmitted has generated greater catastrophism and the consequent false news has generated the opposite effect: misinformation, confusion, and doubts regarding what the media communicated and the consequent uncertainty ( $\underline{\mathrm{PAHO}, 2020})$.

As stated by the WHO (2020b) and PAHO (2020), in a pandemic, misinformation or distortion of the news can negatively affect human health and produce a negative impact on people's mental health. These results generated worldwide concern, joining efforts between different organizations to combat the spread of misinformation and promote access to accurate information based on scientific and evidence data (AleixandreBenavent et al., 2020; WHO, 2020a; PAHO, 2020). However, the consumption of such quantity and quality of information, in addition to its distortion, makes people obstruct their perception of what really happens.

\section{Perception of the severity of COVID-19}

Starting from the theoretical framework of Constructivism when speaking of perception, refers to the construction of the reality of each individual. Constructivism starts from the premise that all reality is the construction of what is perceived (Von Foerster, 1988; Von Glasersfeld, 1988; Watzlawick, 1988). From this epistemological point of view, reality is considered as an individual construction that is co-constructed (in an interactional sense) between the subject and the environment, "an organism is never capable of recognizing, describing or mimicking reality and can only build a model that somehow approaches it" (Ceberio and Watzlawick, 1998, p. 74). In this construction of reality, many factors are put into play, individual, family, contextual, economic, political, social factors, etc. 
In this way, the perception of the severity of the contagion will be influenced by the information received through the media, the predominant emotions at that time in the immediate and general context, the health or organic pathology history, age, the evolution of the contagion of the disease in the immediate environment, the cognitive structure of each person, among other variables (Fernández-Ballesteros and Sánchez-Izquierdo Alonso, 2020; González Gacel et al. 2021; Molero Jurado et al., 2020; Ramos -Vera, 2020). All of these factors, in turn, influence what people do, think, and feel, recursively.

While there is much research on COVID-19 carried out with the general population, limited specific research on the population at risk in the context of a pandemic was found. For example, in Spain (FernándezBallesteros and Sánchez-Izquierdo Alonso, 2020), the severity with which people over 60 years of age perceive Covid-19 was investigated, comparing them with other situations they have experienced throughout their lives, where $71 \%$ considered it a very serious disease and $26.8 \%$ categorized it serious. The perception of severity appears to be high, based on the findings of this research. Also in Spain, it was sought to identify risk factors on the perception of threat to COVID-19, in which it was concluded that such perception is generalized.

In the present investigation, the initial hypothesis was that the perception of severity to the contagion of COVID 19 was high in the first month of quarantine, decreasing towards the ninth month of isolation. The general objective of the same was to evaluate the perception of the severity of contagion in the population at risk in the Argentine Republic. As specific objectives:

1. It was sought to compare the perception of the severity of infection in the population at risk in the first month of quarantine versus the ninth month.

2. Contrast the perception of the severity of contagion in the population at risk compared to the general population.

3. Analyze in the population at risk, the responses of those who contracted the virus versus those who did not.

\section{METHOD}

For this research, a descriptive cross-sectional study was carried out. Although the survey was carried out in a single moment, the formulation of the question allowed us to compare the perception of severity in two different moments of the quarantine. The sampling was non-probabilistic, of volunteers, and a large number of respondents were reached with a wide age and geographic coverage. However, the gender quotas did not correspond to the real distribution in the population, which may suggest the presence of bias in the conclusions since $85 \%$ corresponded to women of the total responses. 
In order to investigate the perception of the severity of contagion in the population at risk, a selfadministered protocol for online distribution was prepared, consisting of a sociodemographic questionnaire and questions related to the perception of the severity of the disease. The questionnaire included sociodemographic variables such as age, gender, occupation, marital status, place of residence, if the person surveyed was a health worker if they considered themselves to be in a risk group, and if they had had COVID 19. To measure the perception, they were asked to answer the severity of the contagion on a scale from 1 to 5 , concerning two moments: in the first month of the pandemic, and at the time of the survey ( 9 months later).

The sample consisted of 4268 individuals (between 18- and 79-years old $\mathrm{M}=39.73, \mathrm{SD}=11.89$ ). $100 \%$ of the sample is made up of citizens residing in the Argentine Republic and a minimum percentage of foreigners living abroad were ruled out. Regarding the population at risk, 1006 respondents $(23.6 \%)$ claimed to be part of the population at risk, 2947 people (69.1\%) were not considered within the population at risk, and 314 (7.4\%) did not know. Of the total sample, 390 people (9.14\%) declared they had contracted COVID-19, of which $19 \%$ belonged to the population at risk (74 people). The non-parametric test of Wilcoxon in order to check if there were significant differences between the scores of the different groups. Thus, it was proven that the perception of the severity of COVID-19 was significantly different between those who considered themselves at-risk population and those who did not, and this occurred both for the perception of the first months and that of the subsequent 9 months.

To measure the responses, a Likert scale was used, where 1 equaled zero risk (asymptomatic patient), 2: moderate risk, 3: medium risk, 4: high risk; 5: very high risk (death). Two comparative moments were taken into account: the first month and nine months of quarantine.

The protocol in Google Forms format was distributed through social networks and distribution lists created by the researchers, during the month of December 2020. Participation was anonymous and voluntary. The data were analyzed with the IMB SPSS Statistics 25 software for Windows, during the first weeks of January 2021.

\section{RESULTS}

In the first place, the perception of the severity of contagion in the population at risk in the first month of confinement was compared with the ninth month of the same. This group consisted of 1006 people. During the first month, $46.6 \%$ of this population responded that the severity of getting COVID 19 was very high, while $7.3 \%$ responded that the risk was zero / low. After nine months of isolation, the perception of the severity of contagion in the population at risk decreased in its maximum and minimum score: thus, $38.5 \%$ responded as very high risk, while $3.4 \%$ responded as null risk, distributing the percentages in the intermediate scores, which is presented in Figure 1 made by authors. 
Figure 1: Perception of the severity of the contagion of the total population at risk

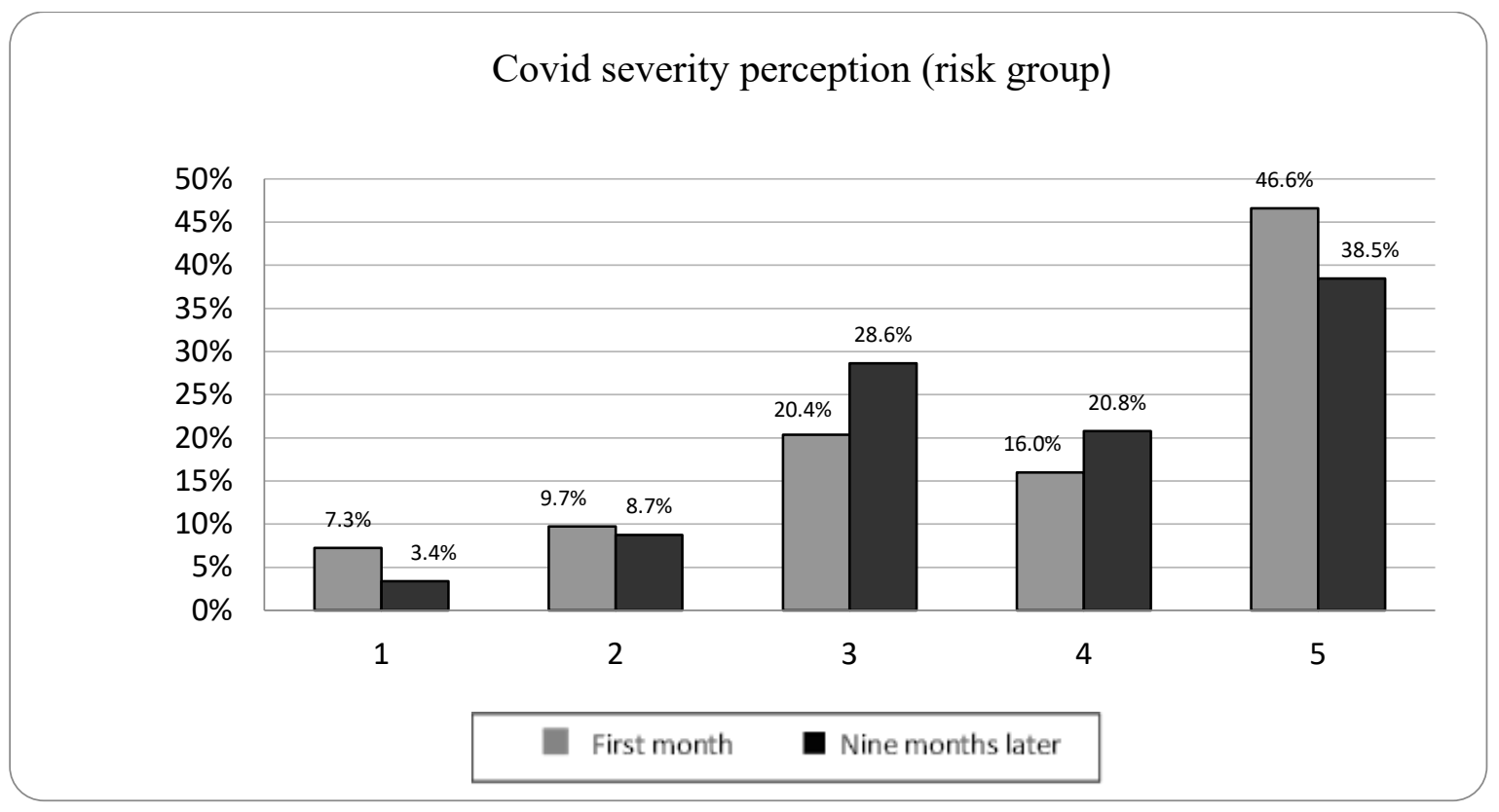

However, the difference between the perception of the first month and at 9 months for those people who belong to risk groups was not statistically significant (the application of the Wilcoxon rank test obtained a value of $\mathrm{p}=0.6)$. On the other hand, in order to generate a comparison with the population at risk, the responses of the population not considered at risk (2948 people) were analyzed. During the first month, the perception of risk of contagion of COVID-19 of 36\% was very high, while $9.5 \%$ risk was zero. At nine months of confinement, the highest response percentage was at medium risk (34.51\%), reducing the very high risk by almost 15\%, which is shown in Figure 2, elaborated by authors.

Figure 2: Perception of the severity of the contagion of the total non-risk population

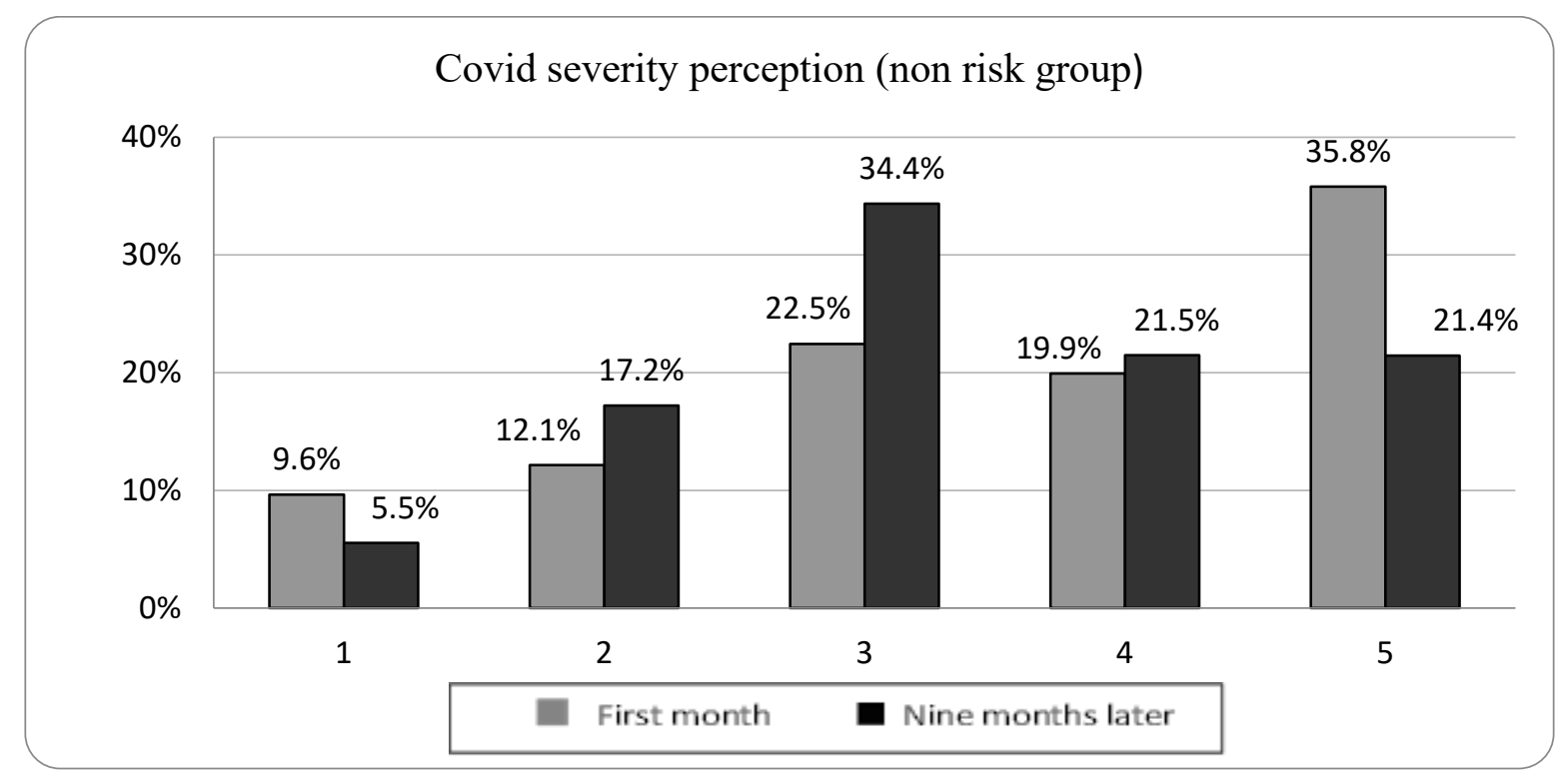


PERCEPTION OF THE SEVERITY OF COVID-19 CONTAGION IN THE RISK GROUP. A COMPARATIVE STUDY AT THE FIRST AND THE NINTH MONTHS OF COMPULSORY ISOLATION

In this case (people who did not belong to risk groups), there were significant differences between both periods analyzed according to the results of the Wilcoxon rank test, which yielded a value of $p=0$.

Finally, the responses of the population at risk that contracted the virus ( 74 people) versus those that did not (778 people) were analyzed. Those who answered not knowing whether they had contracted the disease were not included in the analysis (152) and two who did not answer. As can be seen in Figures 3 and 4, in the first month of quarantine the most marked differences in scores were in very high risk of those who contracted the virus (36.5\%) versus those who did not (48.3\%) and at moderate risk: those who had COVID $19(18.9 \%)$ versus those who did not (9\%). At the ninth month, the marked difference scores were at zero risk: those who contracted COVID 19 (8.1\%) and those who did not contract (2.8\%) and high risk: those who contracted the virus (13.5\%), versus those who did not become infected (21.2\%). The results have been presented in Figure 3 and Figure 4.

Figure 3: Perception of the severity of the contagion of the population at risk that contracted the virus

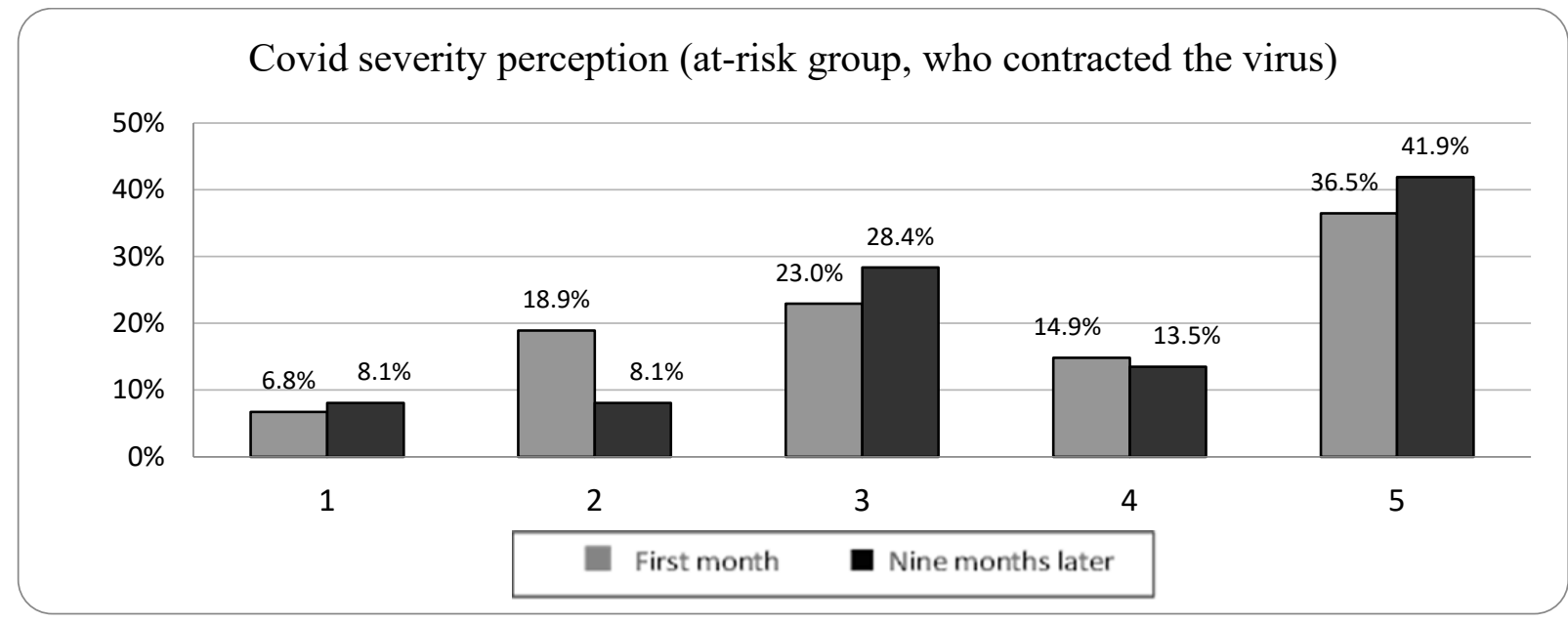

Figure 4: Perception of the severity of the contagion of the population at risk that did not contract the virus.

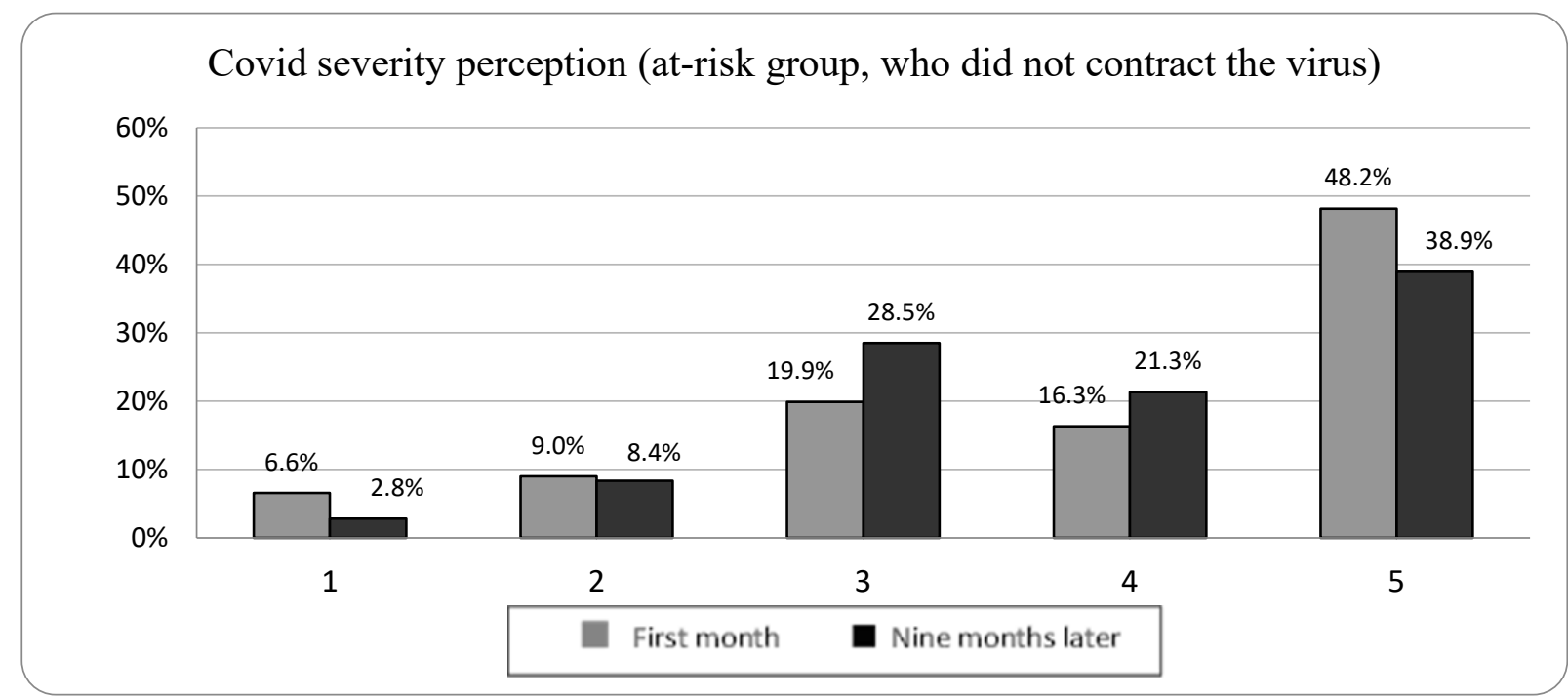




\section{DISCUSSION}

Preventive isolation and biweekly planning were reported sequentially and of course, the pandemic itself produced emotional, cognitive, and behavioral changes in most of the people on the planet. Diverse are the investigations that have shown the irruption of anxiety, fear, and anguish enhanced by the uncertainty generated by the crisis of a new situation and without control factors and with a plan elaborated on the evolution of cases as the pandemic progressed (Ceberio, 2020). Therefore, it led to the perception of the severity of the contagion fluctuating according to the personal experiences and the close environment that each person experienced.

The hypothesis raised in the present investigation was that the perception of the severity of the COVID 19 contagion decreased in the ninth month compared to the first month of isolation, in the population at risk. Although in the results it is observed that in the population considered non-risk the perception of risk of contagion decreased as the months passed, the values remained between the medium, high, and very high percentages. The risk population score remained in the very high risk margins (both in the first month: 46.7\%, and in the ninth: 38.5\%) and medium risk (first month: 20.4\%; ninth month: 28.6\%). As can be seen, there were variations, but the scores are still the highest in the first month as in the ninth. These percentages show that the very high perception of the risk of contagion - almost $50 \%$ occurs in the first month - is due to the fact that this sector of the population is the most exposed to the possibility of contracting the disease, so is actually the most affected by the virus complications and also the one that most protects itself from contagion. The protection and care for this population were encouraged both by the people who were emotionally close to them, as well as by the media that specifically noted the special care for this sector (Aleixandre-Benavent et al., 2020; Fernández-Ballesteros and Sánchez-Izquierdo, 2020).

In the population not considered at risk, significant differences were noted, as the very high risk decreased from $35.8 \%$ to $21.4 \%$ and the average risk increased from $22.5 \%$ to $34.4 \%$. As can be seen, it is an inversely proportional relationship; the values of decrease in the perception of very high risk were transferred to the perception of medium risk, while the values of the high risk remained constant (19.9\%/21.5\%). Based on the hypothesis that as people decrease their perception of risk, they restrict their care, we can say that it is fulfilled to the extent that infections increased exponentially in the last quarter of 2020.

As a result of the extension of the quarantine, the initial states of fear and anxiety were changing due to a feeling of confinement, annoyance, intolerance, among others (Ceberio, 2021). This has led to people thinking, feeling, and acting differently at the beginning of confinement versus the ninth month. Regarding hygiene and care habits, greater neglect began to be noticed, for example in personal hygiene, the use of masks, social distance, etc. And, on the other hand, tools were sought to reduce the emotional stress of the pandemic, such as, for example, starting to carry out social and recreational activities. 
This becomes a circuit, where the dangerousness of the contagion is considered less and less lethal by the population that is not at risk, which reduces their care and brings consequences in the number of high infections, and the severity with which at-risk population experiences it.

Regarding the population at risk of those who contracted COVID-19 versus those who did not, we could say that the marked differences in scores are influenced by how each person went through the disease, either in an asymptomatic way or in a very serious way. Of the people who responded that they had had COVID-19, it is not specified in which month they had it, so the ninth month is taken as a reference to analyze whether the infection of the virus is a variable that influences the perception of its severity. In the ninth month, the main difference (without being significant) was at zero risk (those who had COVID-19: $8.1 \%$ versus 2.8\% of those who did not). It is considered that this point depends on the personal experience of how each person went through it. From people considered at risk who did not present symptoms, even those that required hospitalization. However, it is not considered that having or not having the virus influences the perception of the severity of infection in the population at risk since no significant differences were demonstrated.

\section{CONCLUSIONS}

The context of the COVID-19 pandemic has been and is difficult for the world's population to cope with, like any unexpected and critical situation. But each country, region, person, or group of people will have their particularities in carrying out the impact, and in part, it has to do with how they perceive how dangerous the presence of the virus is.

The results mark a comparative axis between the population at risk and the general population, and the population at risk with and without having been infected with COVID-19, but little significant differences appear in the values of the "very high" category for all the segments explored. It should be noted that both the risk population, as well as the general population, the risk population that did not contract the virus and the one that was infected, was in this last and only group where the values of the 9th month exceeded those of the 1 st month in the category "very high" (not in the rest), although not in a relevant percentage. And it only reached significant levels (1st and 9th months comparison) in the general population.

It is possible to hypothesize how much of the increase or decrease in the values of risk perception in each of the categories, inter-categories, and inter-groups has to do with both real and reliable information such as "false news" or supplied by the media, or issues of a labor or economic nature. But this aims to establish new research that collates such factors. 
The results of this research allow us to reflect on the repercussions that the perception of the severity of the contagion of COVID-19 has over the months, on the behavior, emotion, and thinking of people. Changes in the perception of the severity of contagion can promote, on the one hand, a more realistic look at what is happening, without being pessimistic or idealistic, with the impact that it implies on an emotional and physical level. And, on the other hand, it can lead to hygiene and health safety habits being neglected, generating a higher rate of contagion.

Therefore, these data can guide new research to analyze the behavior of people during the pandemic and post-pandemic, to plan measures that include the physical and mental health of people, as well as to think about mental health strategies to promote primary prevention and assistance programs in the context of the COVID 19 pandemic.

FUNDING: The authors did not receive any external funding.

CONFLICT OF INTEREST: The authors declare no conflict of interest.

\section{REFERENCES}

1. Aleixandre-Benavent R., Castelló-Cogollos L. and Valderrama-Zurián, J. C. (2020). Information and communication during the first months of Covid-19. Infodemic, misinformation and the role of information professionals. International Journal of Information and Communication, 29 (4). http://dx.doi.org/10.3145/epi.2020.jul.08

2. Aliaga Tinoco, S. (2020). Síntomas ansiosos y depresivos en población general y personal médico del Hospital Cayetano Heredia asociados a la cuarentena y atención de la pandemia COVID-19 en Lima [Anxious and depressive symptoms in the general population and medical personnel of the Cayetano Heredia Hospital associated with the quarantine and care of the COVID-19 pandemic in Lima]. Faculty of Medicine, 202292-202292. https://hdl.handle.net/20.500.12866/7889

3. Arias Molina, Y., Herrero Solano, Y., Cabrera Hernández, Y., Guyat, DC, \& Mederos, Y. G. (2020). Psychological manifestations in the face of the epidemiological situation caused by COVID-19. Habanera Journal of Medical Sciences, 19.

4. Bao Y., Sun Y., Meng S., Shi J., Lu L. (2020). 2019-nCoV epidemic: Address mental health care to empower society. The Lancet. 2020; 395 (10224): e37-e38. https://doi.org/10.1016/S0140- 
5. Brown, S. M., Doom, J. R., Lechuga-Peña, S., Watamura, S. E. and Koppels, T. (2020). Stress and parenting during the global COVID-19 pandemic. Child abuse \& neglect, 104699.

https://doi.org/10.1016/j.chiabu.2020.104699

6. Cao, X. (2020). COVID-19: immunopathology and its implications for therapy. Nature reviews immunology, twenty (5), 269-270. https://doi.org/10.1038/s41577-020-0308-3

7. Ceberio, M. R. and Watzlawick, P. (1998). The construction of the universe. Herder.

8. Ceberio, M. R (2021). Psychologists at the Front: Care During the Covid-19 Crisis. From toxic emotions to psychological health. Arch. Med, 225-237.

9. Ceberio M.R. (2020). Los barbijos emocionales [The emotional chinstraps]. Akadia

10. Clerkin, K. J., Fried, J. A., Raikhelkar, J., Sayer, G., Griffin, JM, Masoumi, A., \& Schwartz, A. (2020). COVID-19 and cardiovascular disease.Circulation, 141 (20), 1648-1655. https://doi.org/10.1161/CIRCULATIONAHA.120.046941

11. Decree 297/2020. (2020) Social, preventive and compulsory isolation. official bulletin of the Argentine Republic. March 19, 2020. https:/www.boletinoficial.gob.ar/detalleAviso/primera/227042/20200320

12. del Mar Molero, M., del Carmen Pérez-Fuentes, M., Soriano, J. G., Oropesa, N. F., del Mar Simón, M., Sisto, M., and Gázquez, J. J. (2020). Psychological factors in quarantine situations: a systematic review. European Journal of Health Research, 6 (1), 109-120.

13. Fang, L., Karakiulakis, G., \& Roth, M. (2020). Are patients with hypertension and diabetes mellitus at increased risk for COVID-19 infection? The Lancet. Respiratory Medicine, 8(4), e21. https://dx.doi.org/10.1016\%2FS2213-2600(20)30116-8

14. Fernández-Ballesteros, R. and Sánchez-Izquierdo Alonso, M. (2020). Impact of COVID-19 on the elderly in Spain: some results and reflections. Clinic and Health, 31 (3), 165-169. Epub 2020 Nov 02. https://doi.org/10.5093/clysa2020a25

15. Galindo-Vázquez, O., Ramírez-Orozco, M., Costas-Muñiz, R., Mendoza-Contreras, L. A., CalderilloRuíz, G. and Meneses-García, A. (2020). Symptoms of anxiety, depression, and self-care behaviors during the COVID-19 pandemic in the general population. Medical Gazette, 156, 298-305. http://dx.doi.org/ 10.24875 / GMM.20000266

16. González Gacel, J., Soler Sánchez, Y., Pérez Rosabal, E., González Sábado, R. and Pons Delgado, S. (2021). Perception of risk from COVID-19 in residents of the Manzanillo municipality. MULTIMED, 25(one). http://www.revmultimed.sld.cu/index.php/mtm/article/view/2015

17. González-Jaimes, N., Tejeda-Alcántara, A., Espinosa-Méndez, C., Ontiveros-Hernández, Z. (2020) Psychological impact on Mexican university students due to confinement during the Covid-19 pandemic. Scielo preprint. https://doi.org/10.1590/SciELOPreprints. 756 
18. González-Díaz, R. R., \& Ledesma, K. N. F. (2020). Organizational culture and business sustainability in SMEs during crisis periods of social confinement. CIID Journal, (1), 28-41.

https://doi.org/10.46785/ciidj.vli1.40

19. Goyal, K., Chauhan, P., Chhikara, K., Gupta, P., \& Singh, M. P. (2020). Fear of COVID 2019: First suicidal case in India. Asian journal of psychiatry, 49, 101989.

https://dx.doi.org/10.1016\%2Fj.ajp.2020.101989

20. Huang, Y., \& Zhao, N. (2020). Generalized anxiety disorder, depressive symptoms and sleep quality during COVID-19 outbreak in China: a web-based cross-sectional survey. Psychiatry Research, 288, 112954. https://doi.org/10.1016/j.psychres.2020.112954

21. Huarcaya-Victoria, J. (2020). Mental health considerations in the COVID-19 pandemic. Peruvian Journal of Experimental Medicine and Public Health, 37(two).

https://doi.org/10.17843/rpmesp.2020.372.5419

22. Inchausti, F., García Poveda, N. V., Prado Abril, J. and Sánchez Reales, S. (2020). Clinical psychology in the face of the COVID-19 pandemic in Spain. Clinic and Health, 31 (2), 105-107. http://dx.doi.org/10.5093/clysa2020a11

23. Jerves Mora, R. S., (2020). Pandemia y ansiedad social [Pandemic and social anxiety]. Revista de la Facultad de Ciencias Médicas de la Universidad de Cuenca, 13-16. https://doi.org/10.18537/RFCM.38.01.03

24. Johnson, M. C., Saletti-Cuesta, L., and Tumas, N. (2020). Emotions, concerns and reflections in the face of the COVID-19 pandemic in Argentina. Ciência \& Saúde Coletiva, 25, 2447-2456. https://doi.org/10.1590/1413-81232020256.1.10472020

25. Molero Jurado M. D. M., Herrera-Peco I., Pérez-Fuentes M. D. C., Gázquez Linares J. J. [Analysis of the threat perceived by the COVID-19 in the Spanish population]. Atencion Primaria. 2020 AugSep;52(7):515-516. DOI: 10.1016/j.aprim.2020.05.001. PMID: 32425290; PMCID: PMC7229958.

26. Khan, S., Siddique, R., Li, H., Ali, A., Shereen, M. A., Bashir, N., \& Xue, M. (2020). Impact of coronavirus outbreak on psychological health. Journal of Global Health, 10 (1), 1-6. https://doi.org/10.7189/jogh.10.010331

27. Lozano-Vargas, A. (2020). Impact of the Coronavirus (COVID-19) epidemic on the mental health of healthcare personnel and the general population of China.Journal of Neuro-Psychiatry, 83(1), 51-56. http://dx.doi.org/ 10.20453/ rnp.v83i1.3687

28. Lozano-Díaz, A., Fernández-Prados, J. S., Canosa, V. F., \& Martínez, A. M. M. (2020). Impacts of confinement due to COVID-19 among university students: Life Satisfaction, Resilience.

29. Masip, P., Aran-Ramspott, S., Ruiz-Caballero, C., Suau, J., Almenar, E., \& Puertas-Graell, D. (2020). Information consumption and media coverage during confinement by Covid-19: over information, 
ideological bias and sensationalism. The information professional (EPI), 29(3).

https://doi.org/10.3145/epi.2020.may.12

30. Medina, J. (2020). SARS-CoV-2 (COVID-19) pandemic: between uncertainty and strength. Medical Journal of Uruguay, 36 (2), 6-11. http://www.scielo.edu.uy/scielo.php?pid=S1688-

\section{6\&script $=$ sci arttext\&tlng=en}

31. Mejia, C. R., Rodriguez-Alarcon, J. F., Garay-Rios, L., Enriquez-Anco, M. G., Moreno, A., HuaytánRojas, K., Huancahuari-Ñañacc Huari, N., Julca-Gonzales, A., Alvarez, C., Choque-Vargas, J., and Curioso, W. (2020). Perception of fear or exaggeration transmitted by the media in the Peruvian population during the COVID-19 pandemic. Cuban Journal of Biomedical Research, 39 (2), e698. http://www.revibiomedica.sld.cu/index.php/ibi/issue/view/14

32. Molero Jurado M. M., Herrera-Peco, I., Pérez-Fuentes M. C., and Gázquez Linares J. J. (2020). Analysis of the threat perceived by COVID-19 in the Spanish population. Primary Care. 52: 7. https://doi.org/10.1016/j.aprim.2020.05.001

33. Moreno-Proaño, G. (2020). Distorted thoughts and generalized anxiety in COVID-19. Science America, 9(2), 251-255. http://dx.doi.org/ 10.33210/ ca.v9i2.314

34. Ozamiz-Etxebarria, N., Dosil-Santamaria, M., Picaza-Gorrochategui, M., \& Idoiaga-Mondragon, N. (2020). Levels of stress, anxiety and depression in the first phase of the COVID-19 outbreak in a sample collected in northern Spain.Public Health Notebooks, 36, e00054020. https://doi.org/10.1590/0102-311X00054020

35. PAHO - Pan American Health Organization (2020). Understand the infodemic and misinformation in the fight against COVID-19. Fact Sheets Covid 19. https://iris.paho.org/handle/10665.2/52052

36. Ramos-Vera, C. A. (2020). Network structure of the impact and threat perception of COVID-19. Cuban Journal of Nursing. 36: e4136. http://www.revenfermeria.sld.cu/index.php/enf/article/view/4136/661

37. Rodríguez-Castellanos, A. and San-Martín-Albizuri, N. (2020). Covid-19, globalization, complexity and uncertainty: some reflections on business management in times of crisis and beyond. GEON Magazine (Management, Organizations and Business), 7 (2), 1-17. https://doi.org/10.22579/23463910.219

38. Sánchez, M. V., \& Águila, H. D. (2020). COVID-19: respuestas psicológicas y maneras de gestionarlas [COVID-19: Psychological responses and ways to manage them]. Hospital Magazine "Dr. Emilio Ferreyra", (1), e33-e34. DOI: 10.5281/zenodo.3856407

39. Santamaría, M. D., Ozamiz-Etxebarria, N., Rodríguez, I. R., Alboniga-Mayor, J. J., \& Gorrotxategi, M. P. (2020). Psychological impact of COVID-19 in a sample of Spanish health professionals. Journal of Psychiatry and Mental Health. https://doi.org/10.1016/j.rpsmen.2020.05.002 
40. Saravia-Bartra, M. M., Cazorla-Saravia, P., \& Cedillo-Ramirez, L. (2020). Anxiety level of first-year medical students from a private university in Peru in times of Covid-19. Journal of the Faculty of Human Medicine, 20 (4). https://doi.org/10.25176/RFMH.v20i4.3198

41. Schmidt, B., Crepaldi, M. A., Bolze, S. D. A., Neiva-Silva, L., and Demenech L. M. (2020). Impactos na Saúde Mental e Intervenções Psicológicas Diante da Pandemia do Novo Coronavírus (COVID-19). https://doi.org/10.1590/1982-0275202037e200063

42. Serra Valdés, M. Á. (2020). Infección respiratoria aguda por COVID-19: una amenaza evidente. [Severe acute respiratory infection (COVID-19): an imminent threat]. Habanera Journal of Medical Sciences, 19(1), 1-5. http://scielo.sld.cu/scielo.php?pid=S1729$\underline{519 X 2020000100001 \& \text { script }=\text { sci_arttext\&tlng }=\text { pt }}$

43. Soca Guzmán, C. A., (2020). Frecuencia de miedo, ansiedad y depresión en gestantes en el contexto COVID-19 en un hospital general de Lima-Metropolitana [Frequency of fear, anxiety and depression in pregnant women in the context of COVID-19 in a general hospital in Lima-Metropolitana]. Repository of the Cayetano Heredia University. https://hdl.handle.net/20.500.12866/8468

44. Tomás-Sábado, J. (2020). Fear and anxiety about death in the context of the COVID-19 pandemic. Journal of Nursing and Mental Health, (16), 26-30. https://doi.org/10.5538/2385-703X.2020.16.26

45. Vázquez, O. G., Orozco, M. R., Muñiz, R. C., Contreras, L. A. M., Ruíz, G. C., \& García, A. M. (2020). Symptoms of anxiety, depression, and self-care behaviors during the COVID-19 pandemic in the general population. Medical Gazette of Mexico, 156(4), 298-305.

https://doi.org/10.24875/gmm.m20000399

46. Von Foerster, H. (1988) The construction of reality. In Watzlawick, P. The invented reality. Gedisa.

47. Von Glasersfeld, E. (1988) Introduction to radical constructivism. In Watzlawick, P. The invented reality. Gedisa.

48. Wang, C., Pan, R., Wan, X., Tan, Y., Xu, L., Ho, C. S. and Ho, R. C. (2020). Immediate psychological responses and associated factors during the initial stage of the 2019 Coronavirus disease (COVID-19) epidemic among the general population in China. International Journal of Environmental Research and Public Health, 17 (5), 1729. https://doi.org/10.3390/ijerph17051729

49. Watzlawick, P. (Ed.). (1988). The invented reality. GEDISA.

50. Wei, Y., \& Shah, R. (2020). Substance Use Disorder in the COVID-19 Pandemic: A Systematic Review of Vulnerabilities and Complications. Pharmaceuticals, 13(7), 155. https://doi.org/10.3390/ph13070155

51. WHO - World Health Organization (2020a). Management of the infodemic on COVID-19: Promote healthy behaviors and mitigate the damages derived from incorrect and false information. Press releases.

52. WHO - World Health Organization (2020b). COVID-19 Pandemic: Countries are urged to take stronger action to stop the spread of harmful information. Press releases. 
53. Zandifar A., Badrfam R. (2020). Iranian mental health during the COVID-19 epidemic. Asian J

Psychiatry. 2020; 51: 1-2. https://doi.org/10.1016/j.ajp.2020.101990 